\title{
Critical Success Factor (CSF) of Tree Planting in Malaysia
}

\author{
Jasasikin Ab Sani ${ }^{*}$, Atikah Mohamed Mustafar ${ }^{1}$, \\ Noriah Othman², Zainul Mukrim Baharuddin'
}

\author{
${ }^{1}$ Kulliyyah of Architecture and Environmental Design, \\ International Islamic University Malaysia, Jalan Gombak, 53100 Kuala Lumpur, Malaysia \\ ${ }^{3}$ Faculty of Architecture, Planning and Surveying \\ Universiti Teknologi MARA, Shah Alam, 40450, Selangor, Malaysia
}

jasasikin@iium.edu.my, noriaho@yahoo.com

\begin{abstract}
Specific critical success factor (CSF) assessment element for tree planting should be produced to monitor construction work in Malaysia. This paper prepared to develop critical success factor for tree planting works in Malaysia. In this study, there were 225 Landscape Architect respondents successfully responded to the survey conducted. The outcome of this paper began with the assessment elements that had to be rated by respondents according to their general assumption on the critical level of each element. Finally, this research establishes a set of critical success factor of tree planting.
\end{abstract}

Keywords: Critical Success Factor; tree planting; quality, construction

eISSN 2398-4279 @ 2018. The Authors. Published for AMER ABRA cE-Bs by e-International Publishing House, Ltd., UK. This is an open access article under the CC BY-NC-ND license (http://creativecommons.org/licenses/bync-nd/4.0/). Peer-review under responsibility of AMER (Association of Malaysian Environment-Behaviour Researchers), ABRA (Association of Behavioural Researchers on Asians) and cE-Bs (Centre for EnvironmentBehaviour Studies), Faculty of Architecture, Planning \& Surveying, Universiti Teknologi MARA, Malaysia.

https://doi.org/10.21834/ajqol.v3i14.178 


\subsection{Introduction}

Malaysia is developing to achieve the vision of Malaysia Beautiful Garden Nation by 2020 . According to National Landscape Department (2011) "The Beautiful Garden Nation is a country where its physical development is balanced with a well-managed green, beautiful and clean environment". Abdullah (2003) cited in Jasasikin (2015) stated that "This vision has boosted rapidly the landscape development throughout the country that can be observed in Putrajaya, Cyberjaya and KLCC".

According to Abdul Rahman (2010),"Many types of research have been carried out on the issues of managing construction quality. However, most of the researchers had been conducting as a whole. It is important to conduct a research in a narrow scope, especially to focus on the area of implementation which plays an important part in construction work, this statement had been supported by previous study. The result of the study would help to guide QLASSIC in addressing assessment and can be a reference in the process of betterment the quality management for landscape work in Malaysia.

The main aim of this study is to developing critical success factor for tree planting works in Malaysia. Besides, this study used a mixed-method approach based on analysis of quantitative and quantitative data collected. The outcome of this paper began with the assessment elements based on a general assumption of the critical level of each element had to be rated by respondents. Finally, it will produce a set of critical success factor of tree planting based on influencing factor.

\subsection{Literature Review}

\subsection{Critical Success Factor in Construction}

Quality Control played huge roles in producing an excellence construction work. The earlier study on critical success factor was conducted by Ronald D. (1961), the research is about critical success factor as the business guidance. Most of the research study construction quality control as a whole, the more specific study must be developed to improvise construction quality. Then, many researcher conducted study on critical success factors (Walid and Tukel, 1996; Ketelhohn,1998; Cooke, 2002; Nguyen et al., 2004; Muhammad et al., 2008; Afshin and Gholamreza, 2012; Jasasikin, 2015).

The critical success factor is developed to make an organisation successful. (Afshin and Gholamreza, 2012) mentioned "the organization should concentrate on the more efficient factors the critical success factor considering their restrictions." There are seven critical success factors for projects that had been listed by Ashley (1986) which are:
i. Construction activities programming
ii. Design planning
iii. The project manager commitment the goals
iv. Project team motivation
v. Project manager technical capability
vi. Control system
vii. Definition of work and its field 
Besides, Afshin and Gholamreza (2012) in their research on Par Garma Company stated that " it is obvious that identifying and ranking the critical success factors of this supreme company, which work in various fields like construction of dam, irrigation and drainage networks, road construction bridge construction, tunnel excavation, construction of concrete and metal heavy building, and mass construction of the residential buildings in cooperation with Ministry of Defence, Road and Urban Development, Energy, Oil, Social Security Organization, Organization of Construction Engineering and Tehran Municipality, could result in achieving reliability and more desirable record and lead to organization's more success". According to this research, quality assessment elements will be establish with the weightage depend on critical level of every elements in ensuring quality for tree planting works.

\subsection{Landscape Construction}

Motloch (2000) stated that "Landscape construction is part of the scope of work in landscape architecture field beside planning, designing and facilities operation." Landscape construction can be separated into two types which are hard-scape and soft-scape.

This research will emphasise more on soft-scape material that is tree planting. Trees plays as an important element in the construction of garden and landscape area. National Landscape Guideline had been produced by National Landscape Department as to define soft-scape material such as trees, shrubs, ground cover and another plant that had to be provided by the contractor.

\subsection{Planting Work Procedure}

Jasasikin (2015) stated the NLG "is divided into nine subtitles according to a parameter of planting works and category of plant materials." There are several categories of the specification for soft-scape construction that had been used for landscape project in Malaysia. This research will deeply study on the tree as a soft-scape element. This is the tree planting procedure list which are:

\section{i. Plant Selection}

Normally, planting selection based on specification provided by consultant or landscape. A list of a plant which contains the name of species, quality, trunk height. Trunk diameter, container/poly-bag size stipulated in planting plan produced by the consultant and approved by the client. At this early stage, it is a must to do nursery visit before actual planting date to make sure the readiness of plant materials according to the specification.

\section{ii. Transporting the Plant}

Transporting the plant material to the site is another critical issue in planting procedures process. Planting material should be handled accordance to proper procedure. Moreover, this procedure of transporting plant material are needed to prevent damage to plant material during the process. National Landscape Department of Malaysia (NLD) had listed the guidelines for plant transporting in National Landscape Guideline (NLG) to ensure the quality of plant can be maintained in the process of transporting.

iii. Site Nursery 
Next, site nursery is a place to temporarily store plant material in the earlier stage before planting on site. According to Gary (2013), "plant cannot be planted right away to be placed in a shaded area and keep the roots moist". Besides, another reason of organise site nursery is to acclimatise plant material with the new environment of the site. At the site nursery, there is monitoring process is carried to ensure to a good condition of the plant is maintained.

\section{iv. Receiving Plant on Site}

Transporting plant from nursery to the site took a long time to be completed. The plant material condition may be ruined during this time. Therefore, when plant material reached on a site, it is important for the client to inspect once again the quality of plant material to ensure only the proper quality of plant material will be accepted on the site.

\section{v. Preparation of Planting Hole}

Before plant material reaches to the site, planting hole should be prepared. In NLG stated that the preparation of planting hole should follow the configuration stipulated in the specification. The planting holes were dug deep and fairly narrow to accommodate root balls. The reason because of the misconception that most trees and shrubs developed deep tap root. NLG has listed down the guideline for specific measurement of planting hole according to plant types.

\section{vi. Setting Up the Tree in the Planting Hole}

Next, after the preparation of planting hole the tree should be carefully placed in the planting hole with the acceptable upright position of the trunk. The position of root ball must be in the middle of the planting hole, and the depth of root ball should be at the position where the trunk flair will be visible when planting work completed. It is important to place the tree or shrub in the planting hole, so it is slightly higher than the level it was growing in the nursery, suggested by Ophardt and Hummel (2011).

\section{vii. Backfilling}

Backfill soil can be formed original soil dug up from planting hole or a new soil mixture imported from the nursery. This process should be implemented after the setting out of a tree in the planting hole and the installation of staking. Moreover, the new soil mixture with the ideal condition can be introduced, or remediation of soil should be done, if the soil condition at the site has been altered during construction work and retreat from natural condition.

\section{viii. Mulching}

Montenegroa et al. (2013) mentioned: "mulching reduced significantly peak discharge and runoff and resulted in a significant increase in soil moisture". In planting establishment, there is two type of mulching which are organic mulching and inorganic mulching. Decomposed materials such as coconut pit, wooden saw dust and more is an example of organic mulch, whereas, inorganic mulch is a material that not decompose 
over time such as geotextile and landscape fabric.

ix. Site Management for Tree Planting

The adaptation of the species to the particular environment in which they are developed, the quality of planting stock, site preparation, planting methods and aftercare is an indicator the performance of plants in the landscape. According to Fini and Ferrini (2011) "to ensure that site conditions are appropriate for the plants in pursuing the sustainable approach to urban greening. Nonetheless, a less ideal site can be modified to enhance plant performance and development and ease of maintenance".

\subsection{Plant Anatomy}

The growth of tree is complicated as it works as an operating machine that grows, take nutrients, breathe, recover from disease and injury and finally reproduce and die. In an earlier study, Dean and Long (1986) reported "the size of the stem at any point varies so that the bending stress due to the wind remains constant.

According to Jasasikin (2015), "the understanding of the ability of the plant to adapt to surrounding force and mechanical stress will determine the importance level of the supportive element in tree planting work". This explains the natural defence ability of each plant toward their mechanical pressure. This are the basic anatomy for tree: i) Formation of crown, ii) Leaf, iii) Crown, iv) Root, v) Trunk, vi) Branch attachment, vii) Growth factors.

Roughly, this section explain the natural defence ability of plant against mechanical stress. The importance level of the supportive element in tree planting works will be discovered according to the understanding of the ability of the plant to adapt to surrounding force and mechanical stress.

\subsection{Methodology}

This study used a mix-method approach which includes on analysis of qualitative and quantitative data collection. Quantitative method is used for developing an initial list of critical success factor for tree planting work.co. Then, supported by a qualitative method in the survey and validating the results at the end stage of this study. There is four type of data collection technique involved in this research which is, literature review, analysis of document sources, survey and a semi-structured interview.

\subsection{Literature Review}

The main aim and objectives of the research proposal are to guide the process of developing literature review and support by data collection later. Moreover, the collections of secondary data of tree planting work elements have been covered as a background of this research in finding the information and idea.

As the study has been carried out based on construction quality assessment in Malaysia. Throughout the study the construction quality assessment, the basic elements of assessment were determined. Therefore, landscape specification has been collected from several agencies. As this study had been made to investigate quality control of tree planting in 
Malaysia based on their CSF.

\subsection{Document Sources}

In the early stage, it begins with a compilation of existing and common soft-scape quality standard applied in Malaysia. The comparison of all quality standard is made to discover similarity and differences of the contents. Moreover, there is three soft-scape construction quality standard collected one from private landscape consultancy (Punt Garden Sdn. Bhd.) and another two from government agencies which are National Landscape Department and Public Works Department. Next, the initial critical success factor list to conduct the survey for the establishment of the final assessment elements had been produced through comparison of items and contents.

As mentioned earlier, a qualitative method is used to validate the result of the study trough triangulation analysis between the finding of literature review, finding of survey result and finding of interviews. Whereas, quantitative method is applied for the development critical success factor.

\subsection{Development of Questionnaire}

Development of questionnaire was based on preliminary studies conducted. Then, secondary data collected are the basis of questionnaire development. The questionnaire was designed to collect the experts' opinions on the critical level of elements in soft-scape construction. It consists of a list of assessment element to be ranked by respondents based on critical success factors using Likert-Scale 1 to 5 . The number indicate the critical level of every element in soft-scape work.

There are four sub-section in this section which separated according to different influencing factors which are defection on tree growth due to failure to comply the specification during planting work, duration of time consumption for rectification due to failure to comply the specification during planting work, level of cost incurrence on rectification due to failure to comply the specification during planting work and level of workload to rectify the element due to failure to comply the specification during planting work.

\subsection{Sampling Design and Procedure}

The data collection will be conducted with an expert group in quality control of tree planting in Malaysia. Respondents of the survey are among Landscape Architect listed in Institution of Landscape Architect Malaysia (ILAM) directory 2008/2009 (ILAM, 2009). There are 225 from 543 respondents successfully responded to the survey conducted. According to Yamanae (1973), "the number of respondents from the population of 500 should be at the minimum of 222". The list of the landscape architect in ILAM directory was arranged according to the sequence of membership number.

The survey was started with landscape architect number one in the list and followed by Landscape Architect number three on the list and so on. If the researcher failed to reach any intended Landscape Architect, the selection was moved to the next number of the person. The process will continue until the last number of the person. Next, the researcher continued the survey by started on the person that left unattended on the first round survey. This 
process continued until the last person on the list.

The survey was mainly conducted through the mail. It will be mailed to the respondent based on address stated in ILAM directory. Before sending the survey, the confirmation of respondent's address has been made through a telephone call. Besides, some of the respondents that reachable by the researcher, the survey form was given by hand and the respondents will answer the survey immediately or return it via mail.

\subsection{Contribution weightage Formula}

The study has calculated the score of assessment elements based on Contribution Weightage Formula (CWF) to generate weightage for CSF. For this study, CWF is a summation of some respondents who had chosen the specific assessment element with certain of contribution toward CSF.

Contribution Weightage $=\Sigma[($ Number of Respondents) $\times($ DCTCSF $)]$

DCTCSF $=$ Degree of Contribution toward Critical success factors

\subsection{Research Framework}

Figure 3.0 illustrates the research framework that will be conducted as to complete this study.

\subsection{Results and Discussion}

This stage illustrates the analysis and the synthesis of data collected from the survey. The analysis began with the rating given to assessment elements in general without the present of influence factor. Then it followed with the weightage comparison of critical success factors based on influencing factors. There are four influencing factor which are defection on tree growth due to failure to comply the specification during planting work, duration of time consumption for rectification due to failure to comply the specification during planting work, level of incurrence on rectification due to failure to comply the specification during planting work and level of workload to rectify the element due to failure to comply the specification during planting work. In this finding and discussion, it will be highlighted the rank and contribution weightage of planting work elements.

\subsection{Contribution Weightage Formula of CSF}

Contribution Weightage Formula was used to demonstrate the degree of contribution on CSF of tree planting assessment elements. For this research, Contribution Weightage formula is a summation of number respondents who had chosen the specific tree planting construction elements with a certain contribution towards critical success factors.

As mentioned before the weightage comparison of critical success factors according to four influencing factors that had been stated before. 


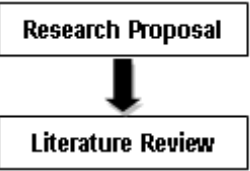

\section{Research kethodology}

\begin{tabular}{|c|c|c|}
\hline & \multirow{3}{*}{$\begin{array}{l}\text { Step 1: Preparation Process } \\
\text { Literature Review } \\
\text { - Identify existing and common soft- } \\
\text { scape quality standard used in } \\
\text { Malaysia. } \\
\text { Survey Questionnaire form } \\
\text { - Developing questionnaire based on } \\
\text { information based on secondary data. } \\
\text { - Identify person to answer survey } \\
\text { question. } \\
\text { - Pilot Study }\end{array}$} & \multirow{3}{*}{$\begin{array}{l}\text { Step 2: Data Collection } \\
\text { - Reviewi and make comparison } \\
\text { between quality standard used in } \\
\text { Malaysia. } \\
\text { - Produce initial list of planting elements } \\
\text { - Conduct survey with } 225 \text { Landscape } \\
\text { Architecture that register with } \\
\text { Institution Landscape Architect } \\
\text { Malaysia (ILAM). }\end{array}$} \\
\hline $\begin{array}{l}\text { Create Initial list } \\
\text { of planting } \\
\text { elements } \\
\text { Stage 2 }\end{array}$ & & \\
\hline $\begin{array}{l}\text { Establishment of } \\
\text { ineighted for } \\
\text { Critical Success } \\
\text { Factor }\end{array}$ & & \\
\hline \multirow[t]{2}{*}{ Stage 3} & & \\
\hline & Calculated the Score of Critic & uccess Factor \\
\hline
\end{tabular}

Stage 4

\section{Produce a set of Critical Success Factor for Trees Planting Works in Kalaysia}

Figure 3.0: Research framework

Table 4.0: Contribution Weightage Formula of CSF- Level of defection

\begin{tabular}{lcccccc}
\hline \multirow{2}{*}{ Elements } & \multicolumn{4}{c}{ Degree of weightage contribution toward CSF } & \multirow{2}{*}{ Total } \\
\cline { 2 - 5 } & 1 & 2 & 3 & 4 & 5 & weightage \\
\hline Soil mixture & $4(4)$ & $11(22)$ & $50(150)$ & $74(296)$ & $86(430)$ & 902 \\
\hline Planting hole & $4(4)$ & $11(22)$ & $50(150)$ & $74(296)$ & $86(430)$ & 815 \\
\hline Root ball & $10(10)$ & $39(78)$ & $59(177)$ & $64(256)$ & $53(265)$ & 786 \\
\hline Finishing \& & $11(11)$ & $45(90)$ & $82(246)$ & $56(220)$ & $32(160)$ & 727 \\
treatment & $24(24)$ & $63(126)$ & $85(256)$ & $46(184)$ & $7(35)$ & 624 \\
\hline Staking & $28(28)$ & $59(118)$ & $92(276)$ & $34(136)$ & $12(60)$ & 618 \\
\hline Mulching & $46(46)$ & $46(92)$ & $79(237)$ & $39(156)$ & $15(75)$ & 606 \\
\hline Trunk diameter & $45(45)$ & $55(110)$ & $74(222)$ & $36(144)$ & $15(75)$ & 596 \\
\hline Trunk height & & & & & &
\end{tabular}

(Source: Jasasikin 2015) 
According to the level of defection as an influencing factor, it was indicating that soil mixture was the top critical success factor with weightage (902), followed by planting hole (815) and root ball size (786). Whereas, the lowest critical success factors were mulching (618), trunk diameter (606) and trunk height (596), as shown in Table 4.0.

Table 4.1: Contribution Weightage Formula of CSF- Duration of time consumption

\begin{tabular}{lcccccc}
\hline \multirow{2}{*}{ Elements } & \multicolumn{4}{c}{ Degree of weightage contribution toward CSF } & \multirow{2}{*}{ Total } \\
\cline { 2 - 5 } & 1 & 2 & 3 & 4 & 5 & weightage \\
\hline Root ball & $10(10)$ & $27(54)$ & $79(237)$ & $73(292)$ & $36(180)$ & 773 \\
\hline Soil mixture & $12(12)$ & $36(72)$ & $67(201)$ & $65(260)$ & $45(225)$ & 770 \\
\hline Trunk diameter & $18(18)$ & $25(50)$ & $86(258)$ & $52(208)$ & $44(220)$ & 754 \\
\hline Trunk height & $18(18)$ & $25(50)$ & $84(252)$ & $57(228)$ & $41(205)$ & 753 \\
\hline Planting hole & $10(10)$ & $47(94)$ & $80(240)$ & $64(256)$ & $24(120)$ & 720 \\
\hline Finishing \& & $18(18)$ & $49(98)$ & $83(249)$ & $50(200)$ & $25(125)$ & 690 \\
treatment & $38(38)$ & $67(134)$ & $74(222)$ & $32(128)$ & $14(70)$ & 592 \\
\hline Staking & $45(45)$ & $49(98)$ & $91(273)$ & $31(124)$ & $9(45)$ & 585 \\
\hline Mulching & & $(S 04)$ & & & \\
\hline
\end{tabular}

(Source: Jasasikin 2015)

Referring to the duration of time consumption to rectify the elements, the lowest weightage belong to finishing \& treatment (690), staking (592) and mulching (585). Meanwhile, root ball size scored the highest weightage (773), then followed by soil mixture (770) and trunk diameter (754). Refer Table 4.1.

Table 4.2: Contribution Weightage Formula of CSF- Level of cost incurrence

\begin{tabular}{lcccccc}
\hline \multirow{2}{*}{ Elements } & \multicolumn{4}{c}{ Degree of weightage contribution toward CSF } & Total \\
\cline { 2 - 5 } & 1 & 2 & 3 & 4 & 5 & weightage \\
\hline Trunk height & $6(6)$ & $28(56)$ & $73(219)$ & $66(264)$ & $52(260)$ & 805 \\
\hline Trunk diameter & $7(7)$ & $26(52)$ & $73(219)$ & $66(264)$ & $53(265)$ & 807 \\
\hline Root ball & $6(6)$ & $31(62)$ & $69(207)$ & $75(300)$ & $44(220)$ & 795 \\
\hline Soil mixture & $4(4)$ & $26(52)$ & $86(258)$ & $66(264)$ & $43(215)$ & 793 \\
\hline Planting hole & $7(7)$ & $35(70)$ & $101(303)$ & $52(208)$ & $30(150)$ & 738 \\
\hline Staking & $22(22)$ & $62(124)$ & $91(273)$ & $42(168)$ & $8(40)$ & 627 \\
\hline Mulching & $33(33)$ & $60(120)$ & $94(282)$ & $32(128)$ & $6(30)$ & 593 \\
\hline $\begin{array}{l}\text { Finishing \& } \\
\text { treatment }\end{array}$ & $10(10)$ & $51(102)$ & $92(276)$ & $44(176)$ & $28(140)$ & 704 \\
\hline
\end{tabular}

(Source: Jasasikin 2015)

Based on the level of cost incurrence it illustrates trunk diameter as the highest score of critical success factor (807) and followed by trunk height (805) and root ball size (795). Whereas, the three lowest critical success factors score are finishing and treatment (704), stacking (627) and mulching (593) as indicates in Table 4.2. 
Ab Sani, J., et.al. / Asian Journal of Quality of Life (AjQoL), 3(14) Nov / Dec 2018 (p.1-12)

Table 4.3: Contribution Weightage Formula of CSF- Level of workload

\begin{tabular}{lcccccc}
\hline \multirow{2}{*}{ Elements } & \multicolumn{5}{c}{ Degree of weightage contribution toward CSF } & Total \\
\cline { 2 - 5 } & 1 & 2 & 3 & 4 & 5 & weightage \\
\hline Soil mixture & $5(5)$ & $25(50)$ & $68(204)$ & $69(276)$ & $59(290)$ & 825 \\
\hline Root ball & $13(13)$ & $21(42)$ & $70(210)$ & $70(280)$ & $51(255)$ & 800 \\
\hline Planting hole & $6(6)$ & $28(56)$ & $75(225)$ & $72(288)$ & $44(220)$ & 795 \\
\hline Trunk diameter & $15(15)$ & $21(42)$ & $81(243)$ & $63(252)$ & $45(225)$ & 777 \\
\hline Trunk height & $17(17)$ & $21(42)$ & $83(249)$ & $58(232)$ & $46(230)$ & 770 \\
\hline Finishing \& & $16(16)$ & $48(96)$ & $81(249)$ & $54(216)$ & $26(130)$ & 701 \\
treatment & & & & & & \\
\hline Stacking & $27(27)$ & $59(118)$ & $86(258)$ & $44(176)$ & $9(45)$ & 624 \\
\hline Mulching & $46(46)$ & $52(104)$ & $73(219)$ & $42(168)$ & $12(60)$ & 597 \\
\hline
\end{tabular}

(Source: Jasasikin 2015)

Soil mixture stated the highest score of critical success factors (825) followed by root ball size (800) and planting hole (795). Meanwhile, the three lowest critical success factor scores are finishing \& treatment (701), stacking (624) and mulching (597). Refer Table 4.3.

Table 4.4: Contribution Weightage Formula of CSF- Level of workload

\begin{tabular}{|c|c|c|c|c|c|}
\hline \multirow[t]{2}{*}{ Elements } & \multicolumn{4}{|c|}{$\begin{array}{c}\text { Contribution Weightage Based on Influencing } \\
\text { Factors }\end{array}$} & \multirow[t]{2}{*}{$\begin{array}{l}\text { Total Contribution } \\
\text { Weightage }\end{array}$} \\
\hline & LD & DTC & $\mathrm{LCl}$ & LWL & \\
\hline Soll mixture & 902 & 770 & 793 & 825 & 3290 \\
\hline Root ball & 786 & 773 & 795 & 800 & 3154 \\
\hline Planting hole & 815 & 720 & 738 & 795 & 3068 \\
\hline Trunk diameter & 606 & 754 & 807 & 777 & 2944 \\
\hline Trunk height & 596 & 753 & 805 & 770 & 2924 \\
\hline $\begin{array}{l}\text { Finishing \& } \\
\text { treatment }\end{array}$ & 727 & 680 & 704 & 701 & 2822 \\
\hline Stacking & 624 & 592 & 627 & 624 & 2467 \\
\hline Mulching & 618 & 585 & 593 & 597 & 2393 \\
\hline
\end{tabular}

The sum of all four influencing factors it illustrates that soil mixture attained the highest critical success factor score which is (3290), then followed by root ball size (3154) and planting hole (3068). The three lowest score belong to finishing \& treatment (2822) followed by stacking (2467) and mulching (2393). As shows in Table 4.4.

\subsection{Conclusion}

The result of the study concluded that there are some lacking in landscape construction quality control. This research has established a set of critical success factor that facilitates 
process of planting work elements for tree based on critical success factors of every element.

Finally, the knowledge and understanding of a right requirement for elements will be the basis for developing a more reliable specification and critical success factor to be used as a document for soft-scape quality control.

\section{Acknowledgement}

The authors would like to thank the International Islamic University Malaysia for supporting this research under the Fundamental Research Grant Scheme (RAGS).

\section{References}

Abdullah A. B. (2003). UcapanPerasmian: PelancaranSambutanHariLandskap Negara, Taman TasikCyberjaya. $\operatorname{Mac}$ 3, 2003.

Abdul-Rahman H., Chen W. and Xiang W. Y. (2010). How Professional Ethics Impact Construction Quality: Perception and Evidence in A Fast Developing Economy. Scientific Research and Essays. Vol.5(23). (pp. 37423749).

Ambrose J. E. and Brandow P. (1992). Simplified Site Design. John Wiley \& Sons.

Afshin P. and Gholamreza A. (2012). Determining the Critical success factor In Construction Project: AHP Approach. Interdisciplinary Journal of Contemporary Research in Business, Vol. 4(8).

Arditi, D., \&Gunaydin, H. M. (1997). Total quality management in the construction process. International Journal of Project Management, 15(4), 235-243.

Dana, M. N., Care, P., Maple, R., Oak, S., Oak, W., \& Oak, R. (n.d.). PLANTING LANDSCAPE TREES AND SHRUBS Preplant Operations, 1-9.

Dean T. and J. Long (1986). Validity of Constant-Stress and Elastic- Instability Principles of Stem Formation in Pinus contorta and Trifolium pratense. Annal of Botany. Vol.58. (pp. 833-840).

Federico, A., Ferrada, X., Howard, R., \& Rubio, L. (2014). Risk management in construction projects : a knowledgebased approach. Procedia - Social and Behavioral Sciences, 119, 653-662.

Fini A., Faoro M., Amoroso G., Piatti R., Frangi P. and Ferrini F. (2011). Effect of Pruning Type on Growth, Physiology and Breaking Stress of Maple Trees. Proceedings of the 87th International. Congress of the International Society of Arboriculture. Sydney (Australia). (pp. 23-27).

Griffith G. K. (2003). The Quality Technician's Handbook. Prentice Hall, Inc. McGraw Hill.

Juran J. M. (1995). The History of Managing for Quality in the United State. ASQC Quality Press Milwaukee.

Ketelhohn W. (1998). What is A Key Success Factor?. European Management Journal. Vol. 16(3).(pp. 335-340)

Merriam, S. B. (1998). Qualitative research and case study applications in education. San Francisco: Jossey-Bass.

Montenegro A. A. A., Abrantes J. R. C. B, De Lima J. L. M. P., Singh V. P. and Santos T. E. M. (2013). Impact of 
Mulching on Soil and Water Dynamics under Intermittent Simulated Rainfall. CATENA. Vol. 109. (pp.139-149).

Motloch J. L. (2000). Introduction to Landscape Design. John Wiley \& son.

Mukhtar (2009). QLASSIC, How It Can Benefit an ISO 9001 Certified Contractor. SHEQ MAG. CIDB. Malaysia. (p.15).

National Landscape Policy (2011). National Landscape Department. NLD. Malaysia.

Ophardt M. and Hummel R. L. (2011). Planting Trees and Shrubs in the Landscape. Washington State University Extension.

Oxford Dictionaries, (online). Available at:

< http://www.oxforddictionaries.com/ms> (6 AUGUST 2016)

Rosniza, A., Akbar, N., Fadhil, M., \&Maisyam, M. (2015). Desirable Characteristics of Malaysian Standard Method of Measurements

( MySMMs ) in Meeting Industry Quality Standards. Procedia - Social and Behavioral Sciences, 202(December 2014), 76-88.

Sani, J. A., \& Othman, N. (2012). Quality Standard and Specification for Soft-scape Construction in Malaysia. Procedia - Social and Behavioral Sciences, 35(December 2011), 260-266.

Walid B., Tukel O. I. (1996). A New Framework for Determining Critical Success/Failure Factors In Projects. International Journal of Project Management. 14(3). (p. 141).

Yamanae T. (1973). Statistic and Introduction Analysis. London. Leonard Hill.

Zatil, S., Syed, H., Mohammad, M. F., \& Ahmad, K. (2014). Enhancing the Quality of Construction Environment by Minimizing the Cost Variance. Procedia - Social and Behavioral Sciences, 153, 70-78. 8NA 